\title{
A comparative study of vitamin $D$ levels between infertile and fertile women in India
}

\author{
Seema Saran \\ Corresponding author: Dr Seema Saran, Assistant Professor, Obstetrics \& Gynaecology \\ Government medical college, Badaun (U.P.) India; Email - seema.saran1@gmail.com \\ Distributed under Attribution-Non Commercial - Share Alike 4.0 International (CC BY-NC-SA 4.0)
}

\begin{abstract}
Objective: The objective of the study was to compare the levels of vitamin D in infertile and fertile women. Material and methods: A total of 150 women coming for treatment for infertility at a semi urban clinic were assessed for vitamin D deficiency. An equal number of women with spontaneous conception served as controls. T test was done to find the difference between the two groups. Result: The mean level of vitamin D in fertile women was $20.37 \mathrm{ng} / \mathrm{ml}$ $( \pm 0.66)$ and in the infertile group was $16.58 \mathrm{ng} / \mathrm{ml}( \pm 0.46)$ but this difference was not statistically significant $(\mathrm{P}=0.06)$. Conclusion: Significant difference in serum vitamin D levels in fertile and infertile women could not be established.
\end{abstract}

Keywords: Vitamin D, infertile, fertile.

The role of vitamin $\mathrm{D}$ in bone health and calcium homeostasis has been long recognised. However, in the past decade, the focus is gradually shifting to the non skeletal benefits of vitamin D. There is increasing evidence that in addition to sex steroid hormones, the classic regulators of human reproduction, vitamin $\mathrm{D}$ also plays a role in modulating the reproductive processes in women and men ${ }^{1}$.

Vitamin D is a steroid hormone, mainly produced in the skin after sunlight exposure. Diet and dietary supplements constitute alternative sources of vitamin D for humans ${ }^{2}$. There are 2 distinct forms of vitamin D - ergocalciferol $\left(D_{2}\right)$ and cholecalciferol $\left(\mathrm{D}_{3}\right)$. Cholecalciferol is formed in the human skin from 7- dehydrocholesterol (7DHC). UV radiation converts 7-DHC to previtamin $\mathrm{D}_{3}$ which is rapidly converted to $\mathrm{D}_{3}$. Green plants, mushroom, fish fat and Cod liver oil are rich sources of ergocalciferol ${ }^{3,4}$.

Vitamin $D_{3}$ is provided either by UV radiation of the skin or from diet and is biologically inactive and requires hydroxylation in the liver and kidneys to produce its active form- 1,25 , dihydroxy vitamin D or calcitriol ${ }^{2}$. Vitamin D status of the body is best indicated by the circulating levels of $25(\mathrm{OH})$ vitamin $\mathrm{D}$ due to its longer half life and higher serum concentration as compared to $1,25, \mathrm{DHCC}^{2}$. Calcitriol acts through binding to specific nuclear receptor VDR, which acts in concert with the retinoid $\mathrm{X}$ receptor (RXR), forming a heterodimer ${ }^{5}$. The VDR-RXR heterodimer binds to vitamin $\mathrm{D}$ responsive elements (VDRE) located in the promoter region of the target genes, thus regulating transcription ${ }^{6}$.

Although the main role of vitamin D is considered to be the absorption of calcium and phosphorus from the gut, the wide distribution of VDR in almost all human tissues and the fact that $3 \%$ of the human genome is regulated by the vitamin $\mathrm{D}$ endocrine system points to a extra skeletal role of vitamin $\mathrm{D}$ in various systems and organs, reproduction being a very important one amongst them ${ }^{2,7}$.

Received: $22^{\text {nd }}$ March 2020. Accepted: $4^{\text {th }}$ May 2020.

Saran S. A comparative study of vitamin D levels between infertile and fertile women in India. The New Indian Journal of OBGYN. 2020; 7(1): 16-9. 
The New Indian Journal of OBGYN. 2020 (July-December); 7(1)

Calcitriol is produced by the decidua in response to IL-B secreted by the blastocyst. Calcitriol regulates the decidual expression of the genes involved in embryo implantation. The presence of blastocyst up regulates the production of the active form of vitamin $\mathrm{D}$ in the endometrium ${ }^{8}$. All these facts point towards a crucial role of vitamin $D$ in reproduction. A study also found that women with higher $25(\mathrm{OH})$ vitamin D levels in the serum and follicular fluid were significantly more likely to achieve pregnancy as compared to women with lower levels of vitamin $\mathrm{D}^{9}$.

Both infertility and vitamin D deficiency are burning health issues in today's world. Infertility is defined as failure to conceive for more than 1 year and affects about 48.5 million couples worldwide with significant psychological, medical and economic consequences ${ }^{10}$. Similarly, an epidemic of vitamin D deficiency has been emerging worldwide, with the prevalence of vitamin D insufficiency nearly doubling from 1994 to $2004^{11}$. In this study we aimed to evaluate the vitamin $\mathrm{D}$ levels of women coming for infertility treatment and comparing them with the Vitamin D levels of fertile women.

\section{Materials and methods}

This study was a cross sectional study conducted on 150 women attending the infertility clinic at Government Medical College, Badaun and Magadh Maternity and infertility clinic, Badaun from February 2018 to January 2019. Informed consent was taken from all patients participating in the study. The study was conducted in accordance with the ethical standards of our institution and the 1964 Helsinki declaration and its later amendments or comparable ethical standards. Serum Vitamin D levels of a total of 150 women coming for infertility treatments were assessed. A similar group size of patients coming with spontaneous conception served as controls. Vitamin D levels were measured by Enzyme Immunoassay Competition Method with a Final Fluorescent Assay (ELFA). T test was done for comparison of results of both the groups.

Inclusion criteria: All infertile women in the age group of 20-40 years were included and healthy fertile women in the same age group served as controls.

Exclusion criteria: History of smoking or tobacco use, use of any hormones or steroids, known vitamin D deficiency, patients with thyroid disorders and autoimmune disorders were excluded from the study.

\section{Results}

Table 1 shows the age profile of the study and control group of women. In this study, the maximum patients of

Table 1: Age analysis

\begin{tabular}{lll}
\hline Age group & $\begin{array}{l}\text { Study group } \\
\text { Number }(\%) \\
(\mathbf{N}=150)\end{array}$ & $\begin{array}{l}\text { Control group } \\
\text { Number (\%) } \\
(\mathbf{N}=150)\end{array}$ \\
\hline$<25$ yrs & $9(6 \%)$ & $48(32 \%)$ \\
$26-30$ yrs & $85(56.6 \%)$ & $65(43.3 \%)$ \\
$31-35$ yrs & $51(34 \%)$ & $32(21.3 \%)$ \\
$>35$ yrs & $5(3.3 \%)$ & $5(3.3 \%)$ \\
\hline
\end{tabular}

study group were of age $26-30$ years $(56.6 \%)$ followed by $34 \%$ of patients in the age bracket of $31-35$ years. In comparison, in the control group, which consisted of fertile women, the maximum number of patients were again in the age bracket of $26-30$ years but $32 \%$ of women were $<25$

and vitamin D levels of both groups

\begin{tabular}{lll}
\hline Categories & Mean vit D levels (ng/ml) & Mean age in yrs \\
\hline Fertile group of women & 20.37 (SEM 0.66) & 26.07 (SEM 0.34) \\
Infertile group of women & 16.58 (SEM 0.46) & 31.28 (SEM 0.34) \\
\hline
\end{tabular}

years of age. Women more than 35 years were $4.6 \%$ in the infertile group and $3.3 \%$ in the control group. Table 2 shows the comparison of age and vitamin D levels in both the groups. As seen, the mean age in the fertile group was 26.07 yrs $( \pm 0.34)$ whereas it was $31.28( \pm 0.34)$ in the infertile group. The mean Vitamin D level in the fertile group was

Table 3: Subgroup analysis of infertile women

\begin{tabular}{lll} 
Categories & Vit D levels $(\mathbf{n g} / \mathbf{m l})$ & Age in years \\
\hline Tubal factors & $17.19( \pm 0.96)$ & $30.02( \pm 0.4)$ \\
PCOS & $15.3( \pm 1.02)$ & $28.18( \pm 0.41)$ \\
Unexplained & $16.41( \pm 0.15)$ & $30.52( \pm 0.24)$ \\
\hline
\end{tabular}
$20.37 \mathrm{ng} / \mathrm{ml}( \pm 0.66)$ and $16.58 \mathrm{ng} / \mathrm{ml}( \pm 0.46)$ in the infertile group. As is seen, the mean vitamin D level was lower in the infertile group; but this difference was not found to be statistically significant $(\mathrm{P}=0.06)$. Table 3 shows the subgroup analysis of vitamin D levels of the women in the infertile group. The women were divided into 3 subgroups on the basis of factors contributing to their infertile status - tubal factors, polycystic ovarian disease (PCOS) and those with no explainable cause. In the tubal group, the mean age was $30.02( \pm 0.4)$ and mean vitamin D level was $17.19 \mathrm{ng} / \mathrm{ml} \mathrm{( \pm}$ 0.96 ). Women with PCOS had a mean age of 28.18 years ( \pm $0.41)$ and vitamin $\mathrm{D}$ levels of $15.3 \mathrm{ng} / \mathrm{ml}( \pm 1.02)$. Those in the unexplained group had a mean age of 30.52 years ( \pm $0.24)$ and mean vitamin D levels of $16.41 \mathrm{ng} / \mathrm{ml}( \pm 0.15)$.

\section{Discussion}

Vitamin D levels are classified in 3 categories deficiency, insufficiency and sufficiency as per Institute of 
The New Indian Journal of OBGYN. 2020 (July-December); 7(1)

Medicine and Euronut Seneca study ${ }^{12}$, Suvimax study ${ }^{13}$, and Goswami et al ${ }^{14}$. The reference levels for serum vitamin $\mathrm{D}$ are - deficiency $<10 \mathrm{ng} / \mathrm{ml}$, insufficiency $10-20 \mathrm{ng} / \mathrm{ml}$ and adequate levels $>20 \mathrm{ng} / \mathrm{ml}$.

Although accumulating evidence from animal and human studies suggests that vitamin D is involved in many functions of the human reproductive system, no comprehensive analysis of the potential relationship between vitamin D status and fertility rates is currently available. On this basis, the purpose of this study was to compare vitamin D levels in fertile and infertile or sub fertile women. This issue is of interest considering that vitamin $\mathrm{D}$ deficiency is easily amenable to correction and oral vitamin D supplementation is cheap and without significant side effects. In a study by Rudrick et al ${ }^{15}$, it was found that vitamin D deficiency was associated in lower pregnancy rates in Non Hispanic whites but not in Asians. Also, vitamin D deficiency was not correlated with ovarian stimulation parameters or with markers of embryo quality, suggesting that its effects may be mediated through the endometrium. Similarly, Fung et al ${ }^{16}$ demonstrated an association between vitamin D intake and biomarker levels on conception. Those with intake at or above the estimated average requirement (intake $10 \mu \mathrm{g} / \mathrm{ml}$ ) and serum levels indicating sufficiency were more likely to achieve a clinical pregnancy.On the other hand, a study by Franasiak JM et al, demonstrated that vitamin D levels had no effect on IVF outcomes following transfer of euploid blastocysts ${ }^{17}$. Similarly, in a study conducted by Fabris et al, no correlation could be found between bio available vitamin D levels and pregnancy rates ${ }^{18}$.

\section{Conclusion}

The statistical significance of the difference in the vitamin D levels in the infertile and the fertile group of women could not be established. So, in our study, we have not been to reach a conclusive relationship between serum vitamin D levels and infertility. As of now, routine assessment of vitamin D levels in women coming for infertility treatment cannot be recommended. Though its role in maintaining bone health is universally accepted, further studies are required to find out subgroup of women in whom its deficiency and its treatment can lead to a better reproductive outcome. Also, since the cut off levels for vitamin D deficiency have been deduced from the effect of vitamin $\mathrm{D}$ on bone health, we may not extrapolate the same levels to define the cut off for deficiency as far as reproductive health is concerned. So, further studies are needed to identify the exact levels and therapeutic supplementation of vitamin D for reproductive health.

\section{Conflict of interest: None. Disclaimer: Nil}

\section{References}

1. Lerchbaum E, Obermayer-Pietschet B. Vitamin D and fertility: a systematic review. Eur J Endocrinol. 2012;166(5):765-78

2. Holick M F. Vitamin D deficiency: review. N Engl J Med. 2007; 357: 266-81.

3. Holick MF, Chen TC. Vitamin D deficiency: a worldwide problem with health consequences. Am J Clin Nutr. 2008; 87:1080s-6s

4. Holick MF. The Vitamin D deficiency pandemic and consequences for nonskeletal health: mechanisms of action. Mol aspects Med.2008; 29(6): 361-8.

5. Rosen CJ, Adams JS, Bikle DD. The non skeletal effects of Vitamin D: an Endocrine Society scientific statement. Endocr Rev. 2012; 33(3): 456-92

6. Haussler MR, Jurutka PW, Mizwicki M, Norman AW. Vitamin D receptor (VDR)-mediated actions of $1 \alpha$, $25(\mathrm{OH})_{2}$ Vitamin $\mathrm{D}_{3}$ : genomic and non genomic mechanisms. Best Pract Res Clin Endocrinol Metab. 2011; 25(4): 543-59

7. Bouillon R, Carmeliet G, Verlinden L. Vitamin D and human health: lessons from Vitamin D receptor null mice. Endocr Rev. 2008; 29(6): 726-76.

8. Vigano P, Lattuada D, Mangioni S, Ermellino L, Vignali M, Caporizzo E, et al. Cycling and early pregnant endometrium as a site of regulated expression of the Vitamin D system. J Mol Endocrinol. 2006; 36: 415-24.

9. Ozkan S, Jindal S, Greenseid K, Shu J, Zeitlian G, Hickmon C, et al. Replete Vitamin D stores predict reproductive success following in vitro fertilization. Fertil Steril. 2010; 94: 1314-9.

10. Mascarenhas MN, Flaxmann SR, Boerma T, Vanderpoel $\mathrm{S}$, Stevens GA. National, regional and global trends in infertility prevalence since 1990: a systematic analysis of 277 health surveys. PLoS Med. 2012; 9(12): e1001356

11. Looker AC, Pfeiffer CM, Lacher DA, Schleicher RL, Picciano MF, Yetley EA. Serum 25-hydroxyvitamin D status of the US population: 1988-1994 compared with 2000-2004. Am J Clin Nutr. 2008; 88:1519-27.

12. Van der Wielen RP, Lowik MR, van den Berg $H$, de Groot LC, Haller J, Moreiras O. Serum Vitamin D 
The New Indian Journal of OBGYN. 2020 (July-December); 7(1)

concentrations among elderly people in Europe. Lancet. 1995; 346: 207-10.

13. Chapuy MC, Preziosi P, Maamer M, Arnaud S, Galan P, Hercberg S. Prevalence of Vitamin D insufficiency in an adult normal population. Osteoporos Int.1997; 7: 439-43.

14. Goswami R, Vatsa M, Sreenivas V, Singh U, Gupta N, Lakshmy R, et al. Skeletal muscle strength in young Asian Indian females after Vitamin D and calcium supplementation: a double blind randomized controlled clinical trial. J Clin Endocrinol Metab. 2012: 97: 4709-16.

15. Rudrick B, Ingles SA, Chung K, Stanczyk FZ, Paulson $\mathrm{RJ}$, Bendikson $\mathrm{K}$. Characterizing the influence of Vitamin D levels on IVF outcomes. Human Reprod. 2012; 27(11): 3321-7.
16. Fung JL, Hartman TJ, Schleicher RL, Goldman MB. Association of Vitamin D intake and serum levels with fertility: results from the Lifestyle and Fertility Study. Fertil Steril. 2017; 108(2): 302-11.

17. Fransiak JM, Molirano T, Dubell EK, Scott K, Ruiz A, Forman EJ, et al. Vitamin D levels do not effect IVF outcomes following the transfer of euploid blastocysts. Am J Obstet Gynecol. 2015; 212: 315 e1-e6.

18. Fabris A, Pacheco A, Cruz M, Puente JM, Fatemi H, Garcia-Velaso JA. Impact of circulating levels of total and bioavailable serum Vitamin D on pregnancy rate in egg donation recipients. Fertil Steril. 2014;102:1608-12.

\section{Seema Saran ${ }^{1}$}

${ }^{1}$ Assistant Professor, Obstetrics \& gynaecology

Government medical college, Badaun (U.P.) India 